\title{
Anti-Ige monoclonal antibody therapy for the treatment of patients with chronic rhinosinusitis: a multi-disciplinary practice review
}

\author{
Shaun J. Kilty ${ }^{1,2,3^{*}}$, Andrea Lasso ${ }^{1}$, Stephanie Santucci ${ }^{4}$, William Yang ${ }^{3,4}$ \\ From Canadian Society of Allergy and Clinical Immunology Annual Scientific Meeting 2014 \\ Ottawa, ON, Canada. 23-26 October 2014
}

\section{Background}

Several treatment options have been described for chronic rhinosinusitis (CRS), yet many patients remain poorly responsive to medical and surgical therapy. Recently, antiIgE monoclonal antibody has emerged as a potential therapy for CRS. However, to date evidence for its efficacy in this patient population is sparse. The purpose of this study is to evaluate the clinical effect of anti-IgE monoclonal antibody therapy for patients with recalcitrant CRS and asthma treated in a multi-disciplinary clinic.

\section{Methods}

A review of the charts for the 194 patients on anti-IgE monoclonal antibody therapy was performed. 20 patients diagnosed with CRS with poorly controlled disease having failed surgical and/or medical therapy were identified. Data extraction targeted demographic details, asthma, environmental allergy and CRS specific disease related data. For data analysis, for nonparametric data the MannWhitney test was used and for binary data Fisher's exact test was used.

\section{Results}

Mean age of the cohort was 49 years (range 33-67); eleven patients were male. Mean IgE level was $331.14 \mathrm{IU} / \mathrm{ml}$ (57.54-1338.96 IU/ml). Mean treatment duration was 17 (3-71) months. The most common skin prick test positive environmental allergens were dust mite (100\%) and cat $(65 \%) .75 \%$ of patients had CRS with polyps. Six patients $(30 \%)$ had AERD. The mean polyp score decreased from 1.8 to $1.0(\mathrm{p}=0.106)$. Patient olfaction improved in 11 patients (55\%) with therapy. Two patients

${ }^{1}$ The Department of Otolaryngology-Head and Neck Surgery, The Ottawa Hospital, Ottawa, ON, Canada

Full list of author information is available at the end of the article on chronic prednisone treatment were able to discontinue this treatment. None of the patients progressed to require surgical treatment.

\section{Conclusions}

Anti-IgE monoclonal antibody therapy allowed for clinical CRS disease control in this cohort of patients with severe and recalcitrant CRS. A well-designed clinical trial is needed to further assess the efficacy and safety of this treatment in the CRS population.

\section{Authors' details}

${ }^{1}$ The Department of Otolaryngology-Head and Neck Surgery, The Ottawa Hospital, Ottawa, ON, Canada. ${ }^{2}$ Ottawa Hospital Research Insitute (OHRI), Ottawa, ON, Canada. ${ }^{3}$ The University of Ottawa, Ottawa, ON, Canada. ${ }^{4}$ Allergy and Asthma Research Centre, Ottawa, ON, Canada.

Published: 18 December 2014

doi:10.1186/1710-1492-10-S2-A24

Cite this article as: Kilty et al:: Anti-Ige monoclonal antibody therapy for the treatment of patients with chronic rhinosinusitis: a multi-disciplinary practice review. Allergy, Asthma and Clinical Immunology 2014 10(Suppl 2):A24.

Submit your next manuscript to BioMed Central and take full advantage of:

- Convenient online submission

- Thorough peer review

- No space constraints or color figure charges

- Immediate publication on acceptance

- Inclusion in PubMed, CAS, Scopus and Google Scholar

- Research which is freely available for redistribution 